\title{
PENINGKATAN PEMASARAN MELALUI STRATEGI BRANDING DAN IDENTITAS UNTUK MOCCA ANIMATION STUDIO MALANG
}

\author{
Sultan Arif Rahmadianto ${ }^{1)}$, Bintang Pramudya P.P ${ }^{2)}$, Tegar Andito ${ }^{3)}$ \\ ${ }^{1,2)}$ Fakultas Sains dan Teknologi, Universitas Ma Chung \\ E-mail: ${ }^{1)}$ sultan.arif@ machung.ac.id, ${ }^{2)}$ bintang.pramudya@machung.ac.id \\ ${ }^{3)}$ Fakultas Seni Media Rekam, Institut Seni Indonesia Yogyakarta \\ E-mail: tegarandito@isi.ac.id
}

\begin{abstract}
Abstrak
Program ipteks bagi masyarakat (IbM) ini bertujuan untuk menerapkan branding dan identitas dalam strategi pemasaran usaha jasa animasi Mocca Animation Studio, Kelurahan Sawojajar, Kecamatan Kedungkandang, Kota Malang. Strategi untuk mencapai tujuan tersebut adalah melalui program IbM yang terbagi dalam dua kegiatan, yaitu (1) pelatihan materi branding dan identitas sebagai alat pemasaran yang efektif khususnya untuk industri animasi dan (2) pendampingan perancangan corporate identity system Mocca Animation Studio. Sasaran program ini adalah studio animasi Mocca di Kelurahan Sawojajar, Kedungkandang, Malang. Kegiatan pelatihan branding dan identitas dilaksanakan dalam satu kali pertemuan dengan co-founder dan CEO Mocca Animation Studio dalam bentuk presentasi dan diskusi. Kemudian kegiatan pendampingan perancangan corporate identity system Mocca Animation Studio dilaksanakan selama kurang lebih 6 bulan dalam bentuk program pendampingan. Keberhasilan program ipteks bagi masyarakat ini ditentukan berdasarkan peningkatan wawasan tentang branding dan identitas sebagai alat pemasaran dan menerapkannya disetiap kegiatan pemasaran di Mocca Animation Studio. Hasilnya adalah meningkatnya pengetahuan dan ketrampilan dalam bidang pemasaran usaha jasa animasi dan adanya buku panduan corporate identity system Mocca Animation Studio sebagai dasar dalam penerapan identitas dan branding khususnya pada kegiatan pemasaran. Hasil ini menggambarkan bahwa program pengabdian pada masyarakat studio animasi Mocca Animation Studio Malang efektif dalam mengenalkan branding dan identitas sebagai alat pemasaran di industri animasi.
\end{abstract}

Kata Kunci: IbM, Mocca Animation Studio, branding, identitas.

\section{PENDAHULUAN}

Industri animasi sudah berkembang sejak tahun 1900an. Permintaan animasi semakin hari semakin meningkat dengan semakin meluasnya penetrasi saluran media digital berupa televisi dan internet. Perkembangan internet sangat pesat dan teknologi yang canggih dan murah membawa pengaruh positif pada perkembangan animasi. Hal ini menjadikan animasi sebagai salah satu industri yang pertumbuhannya paling cepat di dunia (Rochman. dkk, 2015). Potensi dari industri animasi ini menjadikan negara-negara yang industri animasinya belum tumbuh berusaha berlomba-lomba untuk mengusung industri ini sebagai salah satu kekuatan ekonomi kreatif di negaranya. Indonesia sebagai negara berkembang juga mempunyai potensi yang tinggi untuk mengembangkan industri animasi.

Mocca Animation Studio merupakan salah satu studio animasi yang terletak di kota Malang memiliki potensi untuk menggerakkan kekuatan perkembangan ekonomi kreatif di Indonesia khususnya di Malang. Studio animasi ini berkembang dari 10 orang personil menjadi hampir 100 personil yang terbagi dalam divisi 2D dan 3D animasi. Perkembangan Mocca Animation Studio ini memiliki dampak positif bagi perkembangan industri animasi di Malang dan bisa menjadi salah satu penggerak ekonomi kreatif Indonesia

Sejarah Mocca Animation Studio dimulai pada tahun 2009, ketika Aditya Yustanto, Eko Purnomo, dan Muhammad Zainuri berkumpul dan pulang ke Malang. Mereka adalah tim divisi animasi studio terbesar di Asia Tenggara yaitu Infiniti Frame Work (IFW) yang berlokasi di Batam. Tujuan berkumpulnya mereka adalah untuk berdiskusi dan berniat untuk mendirikan sebuah studio animasi yang dikelola oleh mereka sendiri secara independen. 


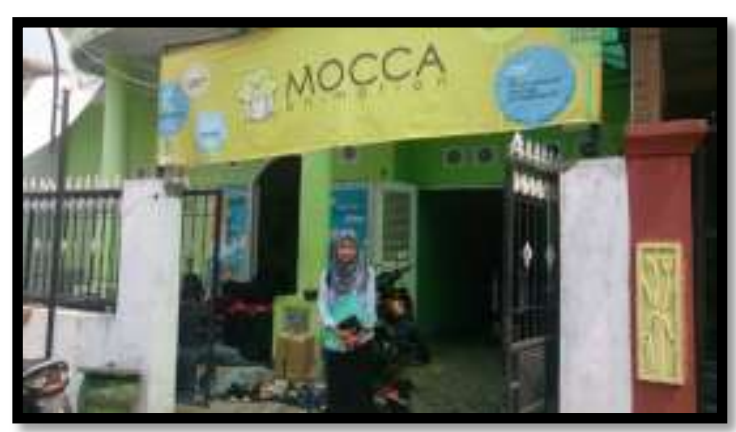

Gambar 1 Kantor Mocca Animation Studio Malang

Melalui inisiasi dari Aditya Yustanto tahun 2013 Mocca Animation Studio terbentuk (Irawati, 2016). Perkembangan industri animasi di Malang bagi Mocca Animation Studio tidaklah mudah. Sebagai studio baru nama Mocca Animation Studio belum begitu banyak dikenal oleh publik. Hal ini diperparah dengan tidak adanya kegiatan promosi yang dilakukan oleh Mocca Animation Studio menyebabkan minimnya jumlah proyek atau orderan animasi yang diterima sehingga membuat perkembangan dari Mocca Animation Studio sangat lambat. Namun tidak berhenti sampai disitu Mocca Animation Studio pada akhirnya membuat semacam strategi dalam bentuk fake project : short animation yang diperuntukan untuk kepentingan kompetisi atau lomba. Tujuan dari Mocca Animation Studio mengikuti lomba / kompetisi adalah untuk menunjukkan eksistensinya di dunia animasi dan kualitas portofolio animasi mereka.

Hasil membanggakan mereka muncul dari sebuah ide membuat film yang mengangkat cerita kucing dan sebatang pohon mahkota. Karya itu dilombakan disebuah festival ITB Apprentice dan berhasil menang sebagai juara 1 dan berhak mendapatkan hadiah 5.000 Dolar AS serta mengikuti program belajar/magang membuat film animasi di Walt Disney Singapura selama dua pekan.

Setelah kemenangan tersebut pertumbuhan dari Mocca Animation Studio semakin meningkat khususnya nama Mocca Animation Studio sudah mulai dikenal oleh publik lokal dan mancanegara. Sehingga mulai banyak berdatangan orderan / service animasi yang masuk di studio sehingga operasional dan perkembangan Mocca Animation Studio mulai membaik.

Mocca Animation Studio juga telah berhasil menjadi penyedia lapangan pekerjaan dibidang animasi yang menyerap banyak tenaga kerja khusunya lokal Malang. Mocca Animation Studio juga membuka program internship / magang yang sangat berguna bagi universitas atau institusi untuk pengenalan dunia kerja. Mocca Animation Studio sejauh ini telah menerima banyak siswa/siswi, mahasiswa/mahasiswi dari berbagai sekolah SMA/SMK dan universitas diseluruh Indonesia diantaranya juga ada Universitas Ma Chung.

Perkembangan dari Mocca Animation Studio yang sangat signifikan tetap memiliki sebuah permasalahan yaitu dibidang pemasaran produk / jasa animasi yang belum maksimal sampai sekarang. Permasalahan mendasar ini kerap terjadi untuk semua startup bisnis kreatif, kurangnya pengetahuan tentang ilmu pemasaran menjadi suatu permasalahan yang lumrah terjadi hal ini dikarenakan biasanya personil startup lebih memprioritaskan kedalam produksi produk/jasa namun mengesampingkan strategi pemasaran produknya padahal itu merupakan ujung tombak dari sebuah bisnis (Riyanti, 2013). Selain itu Mocca Animation Studio masih tergolong baru sebagai bisnis animasi dan belum memiliki brand awarness yang kuat. Untuk mengkover dan memecahkan masalah tersebut diperlukan transfer IPTEK yang tepat guna mengatasi permasalahan tersebut.

Program pemberdayaan masyarakat ini bertujuan untuk mengenalkan dan menerapkan branding dan identitas dalam strategi pemasaran usaha jasa animasi Mocca Animation Studio, Kelurahan Sawojajar, Kecamatan Kedungkandang, Kota Malang. Strategi untuk mencapai tujuan tersebut adalah melalui program $\mathrm{IbM}$ yang terbagi dalam dua kegiatan, yaitu:

1. Pelatihan materi branding dan identitas sebagai alat pemasaran yang efektif khususnya untuk industri animasi.

2. Pendampingan perancangan corporate identity system Mocca Animation Studio.

\section{Permasalahan}

Berdasarkan observasi dan wawancara yang telah dilakukan kepada mitra IbM Mocca Animation Studio dapat disimpulkan ada beberapa permasalahan mendasar, berikut klasifikasi permasalahan mitra berdasarkan skala prioritas :

1. Mocca Animation Studio belum memiliki wawasan tentang ilmu branding dan identitas untuk menunjang pemasaran produk animasi.

2. Mocca Animation Studio belum memiliki dokumen standar sistem identitas / corporate identity system sebagai panduan penting penerapan identitas untuk berbagai kebutuhan pemasaran untuk tetap menjaga konsistensi identitas. 


\section{Solusi}

Berdasarkan identifikasi permasalahan pada mitra maka solusi yang ditawarkan adalah:

1. Memberikan pelatihan / workshop singkat tentang branding dan identitas untuk implementasi pemasaran produk animasi.

2. Membimbing dalam perancangan dokumen standar sistem identitas / corporate identity system sebagai panduan penting penerapan identitas untuk berbagai kebutuhan pemasaran dalam menjaga konsistensi identitas.

\section{Target Luaran}

Target luaran yang akan dihasilkan dari program pengabdian pada masyarakat oleh Tim Pengabdi berdasarkan aspek permasalahan dan solusi adalah sebagai berikut:

1. Meningkatnya kemampuan mitra dalam pemahaman branding dan identitas untuk strategi pemasaran produk animasi.

2. Adanya buku panduan corporate identity system Mocca Animation Studio sebagai dasar dalam penerapan identitas dan branding khususnya pada kegiatan pemasaran.

\section{METODE KEGIATAN}

Berdasarkan solusi yang ditawarkan, pelaksanakan program IbM ini terbagi dalam dua kegiatan, yakni pelatihan dan program pendampingan pendampingan perancangan dokumen corporate identity system. Uraian dua kegiatan tersebut sebagai berikut:

1. Pelatihan dilaksanakan selama satu hari. Total waktu pelatihan adalah selama delapan jam. Mitra menentukan perwakilan pelatihan dan terpilih CEO Mocca Animation Studio untuk mengikuti pelatihan ini. Pelatihan dilaksanakan di kantor Mocca Animation Studio. Materi utama pelatihan adalah branding dan identitas sebagai alat pemasaran produk yang efektif. CEO Mocca Animation Studio tersebut kemudian ditugaskan mensosialisasikan ke tim divisi pemasaran. Pelatihan ini merupakan solusi dari belum dimilikinya wawasan tentang ilmu branding dan identitas untuk menunjang pemasaran produk animasi. Target dari pelatihan ini adalah meningkatnya kemampuan mitra dalam pemahaman branding dan identitas untuk strategi pemasaran produk animasi.

2. Program pendampingan perancangan dokumen standar sistem identitas / corporate identity system Mocca Animation Studio mengadopsi model perancangan branding identity Wheller
(2009) yaitu: (1) identifikasi masalah (2) sintesis (3) desain (4) revisi (5) produksi. Program pendampingan yang dilakukan dilakukan untuk mengatasi permasalahan belum dimilikinya dokumen standar sistem identitas korporat (corporate identity system). Program pendampingan ini dilaksanakan selama kurang lebih 6 bulan dengan target luaran meningkatnya kualitas strategi pemasaran/promosi melalui dokumen standar sistem identitas korporat. Selama program ini berjalan posisi mitra adalah sebagai narasumber / klien terkait kebutuhan perancangan.

Partisipasi yang diberikan mitra berupa dukungan dan komitmen pelaksanaan program IbM, yaitu dengan menyediakan fasilitas tempat untuk kegiatan. Dukungan mitra lainnya adalah pemilihan perwakilan sebagai peserta pelatihan. Instrumen yang digunakan pada program IbM ini meliputi (a) laptop (b) kamera (c) set alat tulis.

Lokasi kegiatan adalah di Kelurahan Sawojajar, Kecamatan Kedungkandang, Kota Malang. Waktu pelaksanaan kegiatan adalah Maret sampai Oktober 2018 (dalam kurun waktu delapan bulan). Adapun durasi kegiatan pengabdian adalah selama kurun waktu delapan bulan yang terbagi dalam tiga tahap, yaitu (1) tahap sosialisasi, (2) tahap pelatihan, dan (3) tahap pendampingan. Evaluasi program pengabdian akan dilaksanakan dengan dua pendekatan sebagai berikut:

1. Evaluasi keberhasilan kegiatan pelatihan dilakukan dengan cara uji pengetahuan secara kualitatif dengan pertanyaan seputar branding dan identitas sebagai alat pemasaran. Pertanyaan akan diberikan sebelum dan sesudah kegiatan serta pada akhir program. Penerapan branding dan identitas untuk semua kegiatan pemasaran dari Mocca Animation Studio merupakan takaran keberhasilan dari pelatihan ini.

2. Evaluasi keberhasilan program pendampingan perancangan dokumen standar sistem identitas / corporate identity system Mocca Animation Studio dilakukan dengan melihat hasil dari desain dan konten yang siap dicetak dan diimplementasikan pada alat pemasaran terkait dari Mocca Animation Studio Kelurahan Sawojajar.

3. Keberlanjutan program akan tetap terjaga dengan adanya penanggung jawab dari mitra yang telah terlatih. Hal ini dibuktikan dengan komitmen tertulis dari peserta pelatihan. 
Rencana proses pelaksanaan kegiatan dapat dilihat pada gambar berikut ini:

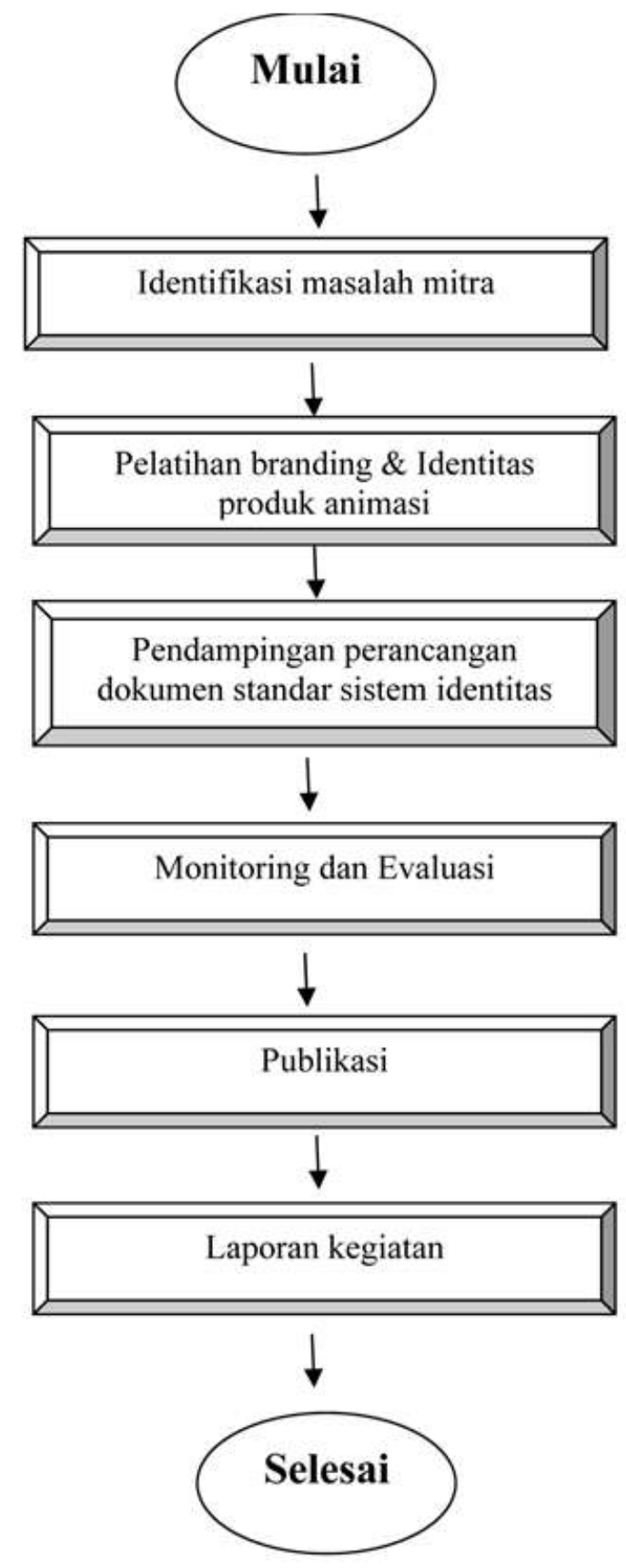

Gambar 2 Rencana Proses Pelaksanaan IbM Mocca Animation Studio

\section{HASIL DAN PEMBAHASAN}

\section{A. Kegiatan Pertama: Pelatihan Materi Branding dan Identitas pada 8 Maret 2018}

Kegiatan pertama berbentuk pelatihan. Kegiatan ini dilaksanakan di kantor Mocca Animation Studio Kelurahan Sawojajar. Total durasi pelatihan adalah delapan jam. Studio animasi Mocca
Animation Studio diwakili oleh Co-Founder sekaligus CEO dari Mocca yaitu Aditya Yustanto. Kegiatan dilaksanakan menggunakan metode presentasi dan diskusi oleh tim abdimas secara tiga tahap, yaitu (1) prakegiatan yang dilaksanakan dengan mengukur tingkat pengetahuan dan pemahaman peserta tentang branding dan identitas di dunia industri kreatif khususnya animasi sebagai alat pemasaran; (2) tahap pelaksanaan yang dilakukan dengan memberikan materi utama, yaitu penerapan branding dan identitas sebagai alat pemasaran yang efektif; dan (3) tahap evaluasi yang dilakukan dengan mengukur tingkat keberhasilan pelatihan.

Dalam pelatihan tersebut disampaikan materi tentang desain branding dan identitas menurut (Wheeler, 2009) meliputi: brand basics, branding identity ideal, brand identity elements, dan Brand forces. Desain pelatihan dengan pendekatan presentasi dan diskusi (Gambar 1) memudahkan peserta dalam memahami materi.

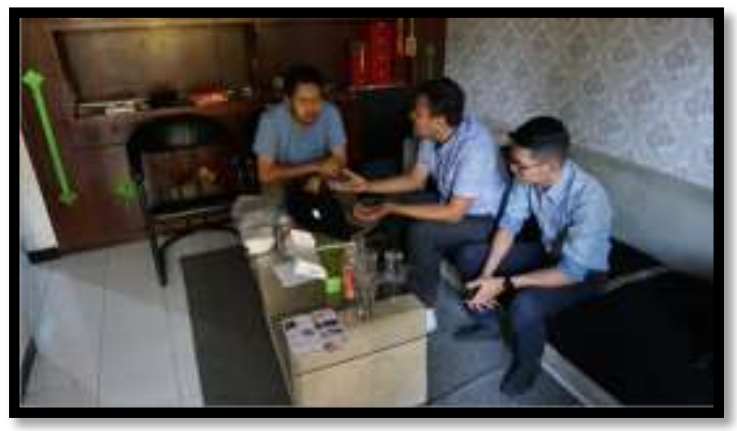

Gambar 1 Kegiatan Pelatihan Mocca Animation Studio.

Evaluasi keberhasilan kegiatan pelatihan dilakukan dengan cara uji pemahaman secara kualitatif dengan teknik wawancara seputar definisi branding dan identitas serta penerapannya sebagai alat pemasaran. Pertanyaan akan diberikan sebelum dan sesudah kegiatan serta pada akhir program. Penerapan strategi pemanfaatan branding dan identitas di setiap kegiatan pemasaran merupakan tingkatan keberhasilan dari pelatihan ini.

Hasilnya Mocca Animation Studio Kelurahan Sawojajar memiliki wawasan yang baik dan memiliki pandangan bahwa implementasi branding dan identitas sebagai alat pemasaran sangat penting dan diakhiri dengan kemauan mitra untuk mulai menggunakan strategi branding dan identitas disetiap kegiatan pemasaran. 


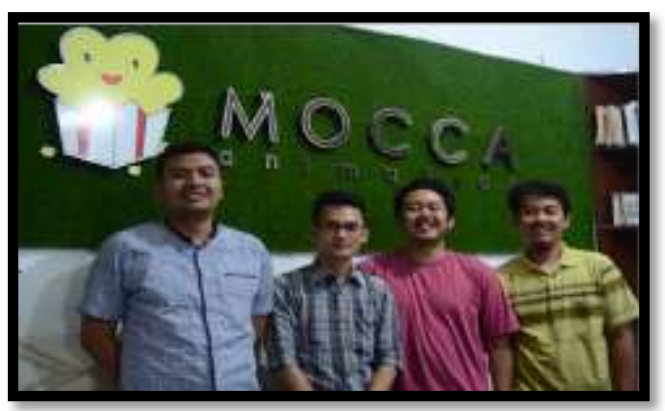

Gambar 2 Sesi foto bersama tim Mocca Animation Studio.

\section{B. Kegiatan Kedua: Program pendampingan perancangan corporate identity system.}

Kegiatan kedua dilaksanakan selama kurang lebih enam bulan yaitu sejak awal bulan April sampai akhir September 2018. Program pendampingan perancangan corporate identity system menggunakan metode perancangan branding identity Wheller (2009) yaitu: (1) identifikasi masalah (2) sintesis (3) desain (4) revisi (5) produksi. Selama program ini berlangsung posisi mitra adalah sebagai narasumber / klien terkait kebutuhan perancangan.

Berikut ini adalah hasilnya:

\section{Identifikasi masalah}

Tahap ini merupakan tahap awal dari keseluruhan proses dengan tujuan untuk penggalian informasi melalui teknik wawancara (Gambar 4.3) untuk mengetahui data Mocca Animation Studio sebagai dasar dalam penentuan konsep visual yang akan digunakan dan pada tahap ini ditemukan data terkait standar dan aturan terkait meliputi: konsep positioning (colorful, cute, and fun), visual dari identitas logo Mocca tetap mempertahankan logogram original, Kemudian untuk warna adalah dominasi warna mocca (kopi) sebagai identitas Mocca Animation Studio yang melambangkan kolaborasi dan kerjasama.

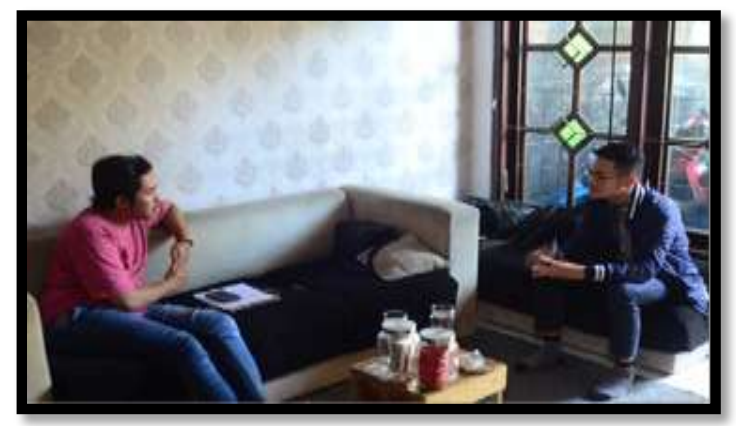

Gambar 3. Wawancara dengan CEO Mocca Animation Studio

\section{Sintesis}

Tahap ini adalah hasil analisis dalam bentuk brief desain untuk panduan corporate Identity System Mocca Animation Studio. Secara garis beras konsep desain yang akan diterapkan mengikuti standar dan aturan terkait sesuai dengan hasil identifikasi masalah. Konten Corporate Identity System Mocca Animation Studio terdiri profil, logo, warna, tipografi, penerapan identitas dan incorrect use.

\section{Desain}

Tahap ini adalah hasil implementasi dari konsep dan brief desain dari buku panduan identitas atau corporate identity system dari Mocca Animation Studio.

\section{a. Profil}

Untuk isi profil singkat Mocca dan menerangkan tujuan dari corporate identity system, dan bagaimana menggunakannya.

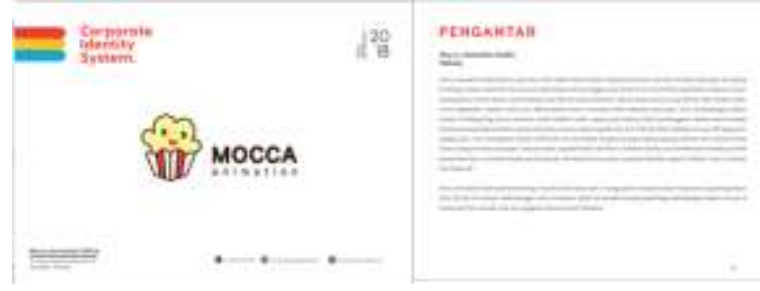

Gambar 3 Desain kover dan profil corporate identity system Mocca

\section{b. Logo}

Menjelaskan konsep, standar dan konstruksi bentuk logo Mocca Animation Studio.
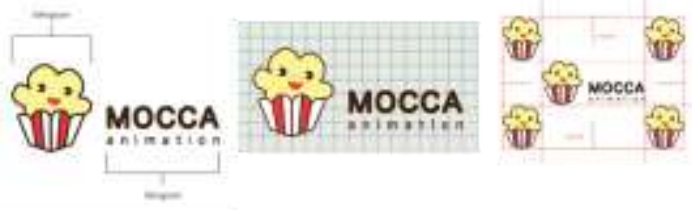

Gambar 4 Desain konten logo corporate identity system Mocca

\section{c. Warna}

Menjelaskan sistem warna yang digunakan, alternatif warna dalam kondisi tertentu, dan informasi kode warna untuk percetakan, screen dan media online pada Mocca Animation Studio. 


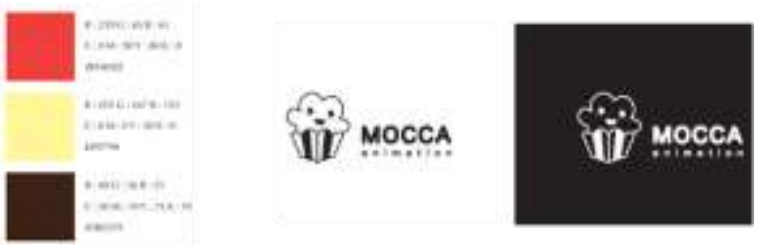

Gambar 5 Desain konten logo corporate identity system Mocca.

\section{d. Tipografi}

Type family (huruf dalam satu keluarga huruf) yang digunakan, alternatif huruf untuk berbagai media yang merupakan penciri dari Mocca Animation Studio.

Heodline
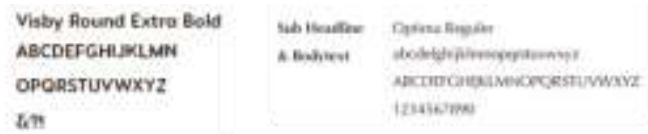

Gambar 6 Desain tipografi corporate identity system Mocca.

\section{e. Penerapan Identitas}

Penerapan identitas pada berbagai media aplikasi yang digunakan Mocca sebagai referensi awal.

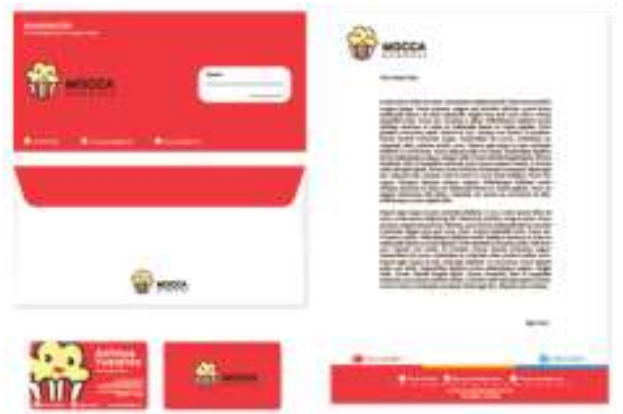

Gambar 7 Desain penerapan identitas corporate identity system Mocca.

\section{f. Incorrect Use}

Berikut ini adalah beberapa contoh penerapan yang salah dan benar logo Mocca Animation Studio disertai dengan contoh kasusnya.

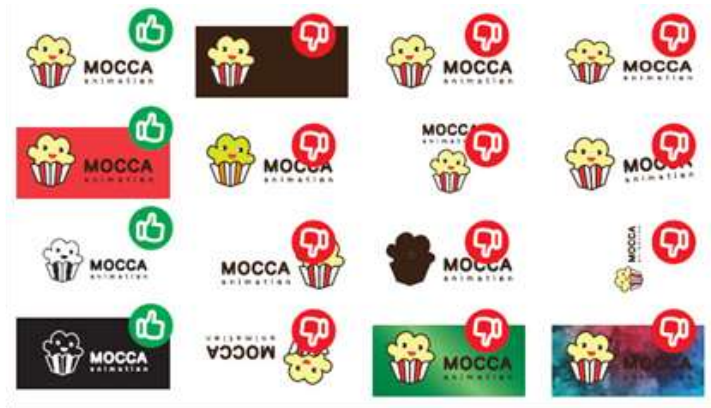

Gambar 8 Desain incorrect use corporate identity system Mocca.

\section{Revisi}

Untuk feedback terkait desain identitas terutama logo yang telah dibuat adalah hanya masalah pada teknis dan pemilihan visual yang kurang pas.
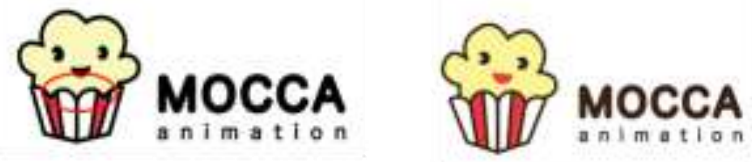

Gambar 9 Desain revisi logo corporate identity system Mocca.

\section{Produksi}

Setelah desain telah disetujui tahap terakhir adalah produksi dari desain corporate identity system tersebut dan memberikannya softfile data kepada CEO Mocca Animation untuk bisa diproduksi sewaktu-waktu.

Evaluasi keberhasilan program pendampingan perancangan corporate identity system dilakukan dengan melihat terbentuknya buku panduan corporate identity system Mocca Animation Studio.

Hasilnya studio animasi Mocca Animation Studio Kelurahan Sawojajar telah memproduksi corporate identity system. Pada tahap terakhir dilakukan kesepakatan dan komitmen mitra untuk secara kontinu melaksanakan penerapan desain sebagai alat pemasaran mereka.

\section{KESIMPULAN}

Berdasarkan pelaksanaan program pengabdian kepada masyarakat dapat disimpulkan bahwa pelatihan branding dan identitas efektif digunakan untuk meningkatkan pengetahuan masyarakat, khususnya studio animasi Mocca Animation Studio Kelurahan Sawojajar tentang branding dan identitas sebagai alat pemasaran yang efektif khususnya untuk industri animasi. Studio animasi Mocca Animation Studio Kelurahan Sawojajar dengan didampingi oleh tim pengabdian telah berhasil menghasilkan buku panduan corporate identity system Mocca Animation Studio. Selain itu, dalam kegiatan ini juga terwujud komitmen untuk melaksanakan implementasi standar desain sebagai alat pemasaran produk mereka secara mandiri. Kegiatan ini diharapkan dapat berdampak pada peningkatan wawasan dan omset usaha jasa animasi di Mocca Animation Studio Kelurahan Sawojajar, Kecamatan Kedung Kandang, Kota Malang. 


\section{REFERENSI}

Irawati, Dahlia, "Menggairahkan Industri Animasi di Malang". Kompas, 2016.

Rianti, Eny, "Peranan Departemen Pemasaran Sebagai Ujung Tombak Keberlangsungan
Usaha PT Produk Rekreasi Kids Fun".Theses, Universitas Gadjah Mada. Yogyakarta, 2013.

Wheeler, Alina. Design Brand Identity. Willey and Sons inc. US, 2009. 